\title{
Common Challenges in Public Sector Performance Measurement in Post-Soviet Countries - Remedies Taken to Escape from the Soviet Legacy
}

\author{
Savalan Suleymanli \\ University of Birmingham, United Kingdom
}

\section{Introduction}

The collapse of the Soviet Union did not only bring substantial changes in the political, social, and economic environments, but it also unearthed hidden deficiencies in all these areas. The public sector of post-Soviet countries was among those fields which considerably suffered from hidden flaws due to the application of artificial measurement tools and management principles by the Soviet nomenklatura. This fragile situation emerged as a result of the demise of the Soviet Union also created a vacuum in the monitoring, assessment and measurement of public sector performance in the newly formed political and administrative environment. Despite the fact that the measurement of public sector performance has always been a significant part of public administration and public performance research, performance measurement in the public sector of postSoviet countries has not been broadly explored in light of the contemporary public sector performance challenges.

At first sight, this topic can be seen as too broad. However, owing to the fact that post-Soviet countries lived under the same political-ideological system for more than seventy years, sharing socialist and collectivist principles and values, this has significantly influenced the public administration of these countries. Therefore, taking into account the similar public sector and governance system of post-Soviet countries, it is decidedly worth having a look at and analyzing public sector performance and its measurement system in these countries by providing comparative examples. It is an undeniable fact that the Soviet legacy persists in post-Soviet countries. As mentioned by Common (2011), the Soviet legacy provides considerable resistance to any reform momentum in post-Soviet countries. This kind of resistance continues to be the major impediment in wrestling with challenges in the public sector and in ensuring sustainability in public sector reforms (UCLG, 2010). From this point of view, the extent to which this legacy has 
Savalan Suleymanli

had an impact on public sector performance and its measurement in post-Soviet countries is explored in the article.

\section{Soviet legacy as a major source of challenges in the public sector and performance measurement in post-Soviet countries}

It is an undeniable fact that the communist principles and values left serious scars in the administrative system of post-Soviet countries. Even nowadays, it is possible to discern that Soviet type management doctrine is widely applied in some postSoviet countries. This fact equally raises some questions that need to be addressed for proper analysis of the public sector measurement of post-Soviet countries, such as, for instance, why these countries were not able to embrace NPM principles in their public administration shortly after the collapse of the Soviet Union; what major hindrances do these countries face in pursuing public sector reforms and relinquishing Soviet type management tools, etc. In order to answer these questions, first of all, clear identification of correlations and contradictions between Soviet style and modern type administrative management principles is needed. To achieve this, let us initially have a look at the core essence of the Soviet performance measurement mechanism and its application methods in the Soviet era.

It is clear that the primary tool of soviet-type bureaucratic administrative system was central planning. Gosplan was the central planning agency responsible for setting up targets for output, investment, labor, and so on (Bryson, 1976; Judith and Denis, 1981). Thus, the fulfillment of plan targets was the main objective of State enterprises and authorities. This kind of planning and functioning approach permeated the performance perception of nearly all public sector organizations in the Soviet Union. Planning and setting target elements of the Soviet-type management can initially be seen as an advanced approach in terms of increasing performance in all State sectors. However, the main deficiency in the planning segment of Soviet-style management was that, in most cases, output goals or targets were not realistic and were set up for the sake of meeting plans without reaching sustainable productive results (Judith and Denis, 1981). This, of course, also negatively affected the performance of public sector organizations in the Soviet Union.

Hence, the performance measurement framework of the public sector in the Soviet Union was based on the planning mechanism. Setting targets and reaching those targets, without analyzing the real outcomes of the carried out policy and without taking into account market signals, was the major performance perception of public sector institutions in the Soviet Union. The interesting point is that the collapse of 
the Soviet Union did not entirely sweep out this perception, and the current measurement system for public sector performance in some post-Soviet countries is still not considerably different from that of the Soviet period.

One of the contradictory features in the newly established political, economic and administrative environment is that "the legacy of the communist type of administration did not provide a strong normative basis for fair and impartial administration..." in post-Soviet countries (Peters, 2008, p.4). However, due to the authoritative and highly centralized nature of governance, this legacy is still the major source of public management in most post-Soviet countries. In addition, systemic corruption and the lack of transparency is one of the biggest challenges in the establishment of an effective performance measurement system in the public sector of post-Soviet countries (Christensen and Laegreid, 2007; Peters, 2008). Of course, some successful efforts have occurred in these countries, and these will be explored later. However, the reality is that, nowadays, post-Soviet countries still share common challenges in the field of public sector and performance measurement, which hinder the bringing of performance management principles to the forefront in the public sector.

From the abovementioned, it is reasonable to claim that Soviet legacy is still deeply embedded in the mindset of most civil servants in post-soviet countries. However, one can question how this legacy obstructs administrative reforms in these countries. In order to find an answer to this question, we need to analyze the management perceptions of civil servants who embrace the Soviet-type management principles. As previously mentioned, Soviet-type management was based on the subordination ("command and control" approach") and meeting plans (Bryson, 1976; Judith and Denis, 1981). Bureaucrats in post-Soviet countries, who are loyal to these principles, see the application of the new management principles as a "deterioration" of the public sector management traditions that have taken root during the Soviet period (Liebert, 2013; Peters, 2008). Hence, despite the changed political, economic, administrative environment, some circles in the public sector in post-Soviet countries obstruct the application of NPM principles in the public sector, such as bringing transparency in public service provision, being open to society and so on. Therefore, it proves to be difficult to pursue complex administrative reforms in the public sector of post-Soviet countries. 


\section{Remedies for challenges in the public sector and performance measurement in Lithuania}

In general, despite the abovementioned common challenges in the public sector and its performance, the pace and quality of public sector reforms, and the efforts to set up an efficient performance measurement framework in post-Soviet countries differs from each other. As an example, Lithuania is one of the successful postSoviet countries, which has made a huge progress in pursuing public sector reforms and moving away from the Soviet legacy. Accession to the EU in 2004 represented one of the driving factors that paved the way for the acceleration of this process. Initially, Lithuania started to apply the principles of performance management and quality-oriented measurement framework in its budgeting system (Nakrosis, 2008). However, the country encountered similar challenges as other post-Soviet countries did, such as the existence of a "red-tape bureaucracy", limited human resources, and so on. Yet, the government managed to ensure sustainability in its public sector reforms, which played an important role in setting up results-based performance management (Pivoras, 2013). The government identified that, as part of the application of new public management principles, the improvement of public service provision can only be achieved if citizens are viewed as customers. Thus, the involvement of citizens in the decision making process and the identification of performance targets positively influenced the establishment of an outcome and results-based performance measurement framework in the public sector (Evans and Evans, 2001).

The use of performance measurement tools by public sector organizations also helps the government to assess performance information provided by these organizations. "The main source of performance information is targets at the level of output, outcomes and effects", and "performance audit is the main instrument of assessing performance" (Nakrosis, 2008, p.63, 64). These kinds of audits are carried out both externally and internally, which gives rise to better monitoring and assessment of the performance of public authorities (World Bank, 2006). Thus, the current public sector performance measurement framework of Lithuania is quite advanced in terms of assessing the efficiency of performance of public sector authorities, as well as value for money for public service provision.

Despite the initiatives taken by the government of Lithuania with the purpose of improving the public sector performance measurement framework, it is too early to claim that the country has totally achieved its goal to apply the principles of performance management in all fields of the public sector. For instance, ensuring 
further transparency and effectiveness and increasing accountability toward its citizens are still major concerns of the government (Nakrosis, 2008).

\section{Remedies for challenges in the public sector and performance measurement in Kazakhstan}

Kazakhstan is one of those post-Soviet countries that struggles to introduce the principles of performance management in its public sector. A majority of top management in public sector organizations were representatives of the Soviet nomenklatura, and these figures are major obstacles in the pursuit of a broad range of reforms in the public sector (Ibrayeva and Nezhina, 2013). Despite these hardships, the government of Kazakhstan has managed to take significant steps toward boosting quality, performance and transparency in the public sector. For instance, the launch of OSS policy played a significant role in liquidating bureaucratic obstacles in public sector provision. Bringing the functions of different government authorities to one center allowed customers to save their time and costs.

In addition, revamping the legal structure was part of the overall public administration reforms. For example, the Decree on "Measures to Modernize the Public Administration in the Republic of Kazakhstan" and the Decree on "Annual Performance Evaluation of the Central State and Local Executive Bodies of Regions, Cities of Republican Status and the Capital" provided the relevant framework for measuring the performance of public sector organizations (Ibrayeva and Nezhina, 2013; State Body Efficiency Evaluation Center of Kazakhstan, 2010).

However, the lack of political will and support, and the low professionalism of public servants curtails the application of performance management principles at all levels of the public sector. Even, the implementation of an advanced "One-stop shop policy" turned out to be a challenge because of pressures by some public authorities. As a matter of example, Janenova $(2008$, p.130) points out that "the reluctance of state bodies to work together and their worries about losing power and opportunities for illegal payment has scaled back OSS policy implementation". Thus, this kind of political and administrative environment constitutes a major hindrance in the pursuit of systematic and quality-based reforms in the public sector of Kazakhstan.

Remedies for challenges in the public sector and performance measurement in Azerbaijan

Despite political and economic challenges in its initial years of independence, Azerbaijan has also managed to pursue successful administrative reforms for the 
improvement of public service provision. However, as in other post-Soviet countries, it is possible to discern the elements of the Soviet bureaucracy in the administrative structure of the government (UN, 2004; Liebert, 2013). Yet, these elements have not taken root in all branches of the public sector in Azerbaijan. For instance, several projects have been implemented by the government with the financial support of international donors, the purpose of which was to modernize the administrative system and improve the legal framework of the public sector (World Bank, 2006).

In addition, some public sector organizations are actively involved in the implementation of joint projects with international and regional donor agencies for acquisition of an advanced experience in the field of performance management and public sector performance measurement. For example, the State Agency for Public Service and Social Innovations, which provides one-stop public services, launched the joint project with the UNDP for enhancing its administrative capacity, efficiency and transparency in providing public services. The application of the principles of performance management and setting up the mechanism of measuring performance was an integral part of this project (UNDP, 2014; Jafarov, 2013).

Summarizing the abovementioned facts, it is possible to identify that post-Soviet countries need to relinquish Soviet administrative legacy for better embracing the key elements of performance management, such as corporate management, performance monitoring, measurement, evaluation, assessment and performance monitoring. However, when we look at the soviet-type of management we see tough "command and control" approach, lack of dialogue between the state and society, artificial planning and measurement. From this point of view, there is a huge difference between the performance management principles and the Soviettype management in the public sector. For this very reason, in post-Soviet countries where soviet legacy persists in the public sector it is very challenging to apply the principles of performance management and apply effective public sector performance measurement techniques.

\section{Why is the measurement of public sector performance important for post- Soviet countries?}

Having reviewed the challenges in public sector performance and measurement once again proves the significance of measuring performance of public sector organizations in post-Soviet countries on the basis of new public management principles. If governments of post-Soviet countries aim to forge trust-based links between public authorities and society, they need to continue their efforts to apply 
performance management principles and set up an advanced performance measurement structure in the public sector. Of course, it would be too naïve to argue that a performance measurement system is the only panacea to all deficiencies existing in the public sector. The multifaceted nature of the public sector, as well as the existence of a wide range of political, economic, social interests, generates numerous factors, which directly affect the overall quality of public service provision. However, having a proper mechanism of measuring performance of public sector organizations is an undeniably important factor for ensuring the smooth functioning of the government and for increasing transparency, accountability, and professionalism in the public sector (Adams et al, 2014; Bolton, 2003).

As mentioned in the foregoing, setting up an advanced performance measurement system plays a decisive role in fostering links and mutual trust between the public and public sector organizations. At first sight, measuring performance can be seen as an internal process of public sector authorities. Therefore, one could question what the direct link is between performance measurement and public trust towards public institutions. In order to answer this question, we need to approach this issue from the "cause and effect" point of view. If we view performance measurement as a cause and increase in performance quality and public satisfaction as an effect, it is possible to discern the mutual relationship between performance measurement and public trust. Another reason why an effective performance measurement framework leads to public trust is that this kind of advanced framework makes it easier for the public to access information about the performance of public sector organizations, thus, increasing the accountability of these authorities vis-à-vis the citizens. Owing to the fact that most public sector institutions fail to build a bridge of trust with citizens, setting an effective performance measurement system can significantly help these institutions to boost their legitimacy in the eyes of public.

Establishing an advanced performance measurement framework is also important for public sector institutions of post-Soviet countries from the organizational learning point of view. Therefore, if the process of measuring performance is seen from the organizational learning angle, this, undoubtedly, will positively affect the overall performance of a public sector organization. Measuring performance does not only mean to set performance indicators. Conversely, measuring performance needs to be seen as an organizational learning process, which in turn leads to unearthing deficiencies and taking preventive measures so as not to repeat those mistakes in the further functioning of the organization. As Jackson points out (1995, p.3), "measuring performance are [is]a means, not an end", which paves the way for sustainable improvement in the performance of public sector institutions. 


\section{Conclusion}

Exploration of the performance measurement and the challenges in this field in post-Soviet countries once again proves that elements of the soviet bureaucracy still endure in the administrative systems of these countries. Despite the fact that the Soviet Union ceased to exist more than twenty years ago, resistance to fundamental public sector reforms is a matter of concern in most post-Soviet countries. Having analyzed challenges in the public sector and performance measurement fields, it is possible to conclude that civil servants who are especially in the top management in government and public sector organizations can pose a major impediment in the pursuit of sustainable public sector reforms and the establishment of an advanced performance measurement framework. This kind of environment leads to the emergence of imbalance between the management/measurement tools applied by the public sector and the public needs, which are far different from those of the Soviet period.

However, having looked at the public sector reform efforts of some post-Soviet countries, it became apparent that not all these countries have followed the same way in revamping their public administration. Via the example of Lithuania, we witness that Baltic States reacted to the changing social, political and economic environment quickly, while embracing European values. Fundamental public sector reforms were also carried out. This, in turn, resulted in the establishment of a near perfect performance measurement framework at the governmental, ministerial, and local levels.

Analysis of the public sector performance measurement framework in post-Soviet countries also made it clear that some post-Soviet countries eschew fundamental administrative reforms due to the highly-centralized nature of their administration. If these reforms are carried out on the basis of new public management principles and an advanced public sector performance measurement framework is established, this may unearth numerous deficiencies in provision of public services. Therefore, the establishment of such a kind of framework is in contradiction with the interests of certain groups in the government and public sector organizations.

Whereas there are some shortcomings in the field of public sector performance in post-Soviet countries, scrutiny of the performance measurement frameworks of public bodies of Azerbaijan, Lithuania and Kazakhstan showed that it is possible to apply quality and outcome-based performance measurement systems across the public sector of these countries. These examples also demonstrated that the public administrations of post-Soviet countries are on the path of further modernization. Meanwhile, the major factor here is to ensure close collaboration among the 
government, society, and public institutions in order to achieve desired outcomes in public service provision. Only in this way can it prove possible to boost efficiency, effectiveness, and quality of performance in the public sector of post-Soviet countries.

\section{References and notes:}

Adams, C, A. et al (2014) Measurement of Sustainability Performance in the Public Sector.Sustainability Accounting, Management and Policy Journal. 5 (1): $46-67$. http://dx.doi.org/10.1108/SAMPJ-04-2012-0018

Bolton, M. (2003) Public Sector Performance Measurement: Delivering Greater Accountability.Work Study. 52 (1): 20-24. http://dx.doi.org/10.1108/00438020310458697

Bryson, P. J. (1976) Scarcity and Control in Socialism. Lexington Books.

Christensen, T. and Laegreid, P. (2007) Transcending New Public Management: The Transformation of Public Sector Reforms. Aldershot: Ashgate.

Common, R. (2011) International trends in HRM in the public sector: reform attempts in the Republic of Georgia. International Journal of Public Sector Management, 24 (5): 421-434. http://dx.doi.org/10.1108/09513551111147150

Evans, A. and Evans, G. (2001) Improving Government Decision-making in Lithuania and Latvia. Journal of European Public Policy. 8 (6): 933-959. http://dx.doi.org/10.1080/13501760110098297

Fryer, K. et al. (2009) Performance Management in the Public Sector. International Journal of Public Sector Management. 22 (6): 478-498. http://dx.doi.org/10.1108/09513550910982850

Ibrayeva, A, R. and Nezhina, T. (2013) Public Sector Reforms in Kazakhstan. In Liebert, S. et al (eds) Public Administration in Post-Communist Countries: Former Soviet Union, Central and Eastern Europe, and Mongolia. Taylor and Francis Group. pp. 43-68.

Jackson, P. M. (Ed). (1995) Measures for Success in the Public Sector. CIPFA. The Chartered Institute of Public Finance and Accountancy.

Jafarov, K. (2013) Azerbaijan's one-stop public service shop is driving up efficiency. [online]. Available from: http://www.theguardian.com/public-leadersnetwork/2013/jul/31/azerbaijan-public-service-assessment-network [Accessed 15 May 2016].

Janenova, S. (2008) The Kazakh One-Stop Shop: Challenges and Recommendations. In Peters, B, G. (Ed) Mixes, Matches and Mistakes. New Public Management in Russia and the Former Soviet Republics. Budapest: TM and Copyright. pp. 117-150.

Shahryarifar, S. (2016) A Defence on the Prominence of Rational Actor Model within Foreign Policy Analysis.Khazar Journal of Humanities and Social Sciences. Khazar University Press.Baku, Azerbaijan.pp.22-29

Judith, P. and Denis, J. B. S. (1981) Planning in the Soviet Union. London: Croom Helm. 
Liebert, S. et al (eds) (2013) Public Administration in Post-Communist Countries: Former Soviet Union, Central and Eastern Europe, and Mongolia. Taylor and Francis Group.

Nakrosis, V. (2008) Reforming Performance Management in Lithuania: Towards Resultsbased Government. In Peters, B, G. (Ed) Mixes, Matches and Mistakes. New Public Management in Russia and the Former Soviet Republics. Budapest: TM and Copyright. pp. 53-115.

Peters, B, G. (Ed) (2008) Mixes, Matches and Mistakes. New Public Management in Russia and the Former Soviet Republics. Budapest: TM and Copyright.

Pivoras, S. (2013) Post-Communist Public Administration in Lithuania. In Liebert, S. et al (eds) Public Administration in Post-Communist Countries: Former Soviet Union, Central and Eastern Europe, and Mongolia.Taylor and Francis Group. pp. 135-160.

State Body Efficiency Evaluation Center of Kazakhstan (2014) Evaluation Directions.[online]. Available from: http://www.bagalau.kz/en/center/usl [Accessed 10 May 2016].

UCLG (2010) Local Government Finance: The Challenges in the $21^{\text {st }}$ Century. GOLD 2010.[online]. Available from: http://www.cities-local governments.org/gold/Upload/gold_report_2/2010\%20EXECUTIVE\%20SUMMAR Y\%20baixa.pdf [Accessed 10 May 2016].

UN (2004) Republic of Azerbaijan. Public Administration. Country Profile.[online]. Available from:

http://unpan1.un.org/intradoc/groups/public/documents/un/unpan023173.pdf [Accessed 09 May 2016].

UNDP (2014) Enhancing the Professional and Operational Capacities of the State Agency for Public Service and Social Innovations.[online]. Available from: http://www.az.undp.org/content/dam/azerbaijan/docs/Governance/asanproject/AZE ASAN_UNDP_Project_Document.pdf [Accessed 13 May 2016].

World Bank (2006) Report On Strategic Planning and Policy Management in Lithuania and Latvia. Report Number: 36930-GLB. Washington. 


\title{
Summary
}

\section{Common challenges in public sector performance measurement in post- Soviet countries - Remedies taken to escape from the Soviet legacy}

\author{
Savalan Suleymanli \\ University of Birmingham, United Kingdom
}

Concentrating on the public sector performance of post-Soviet countries, this article attempts to identify the main challenges in performance measurement field of post-Soviet countries in the context of changed State and society relationship after the collapse of the Soviet Union. In addition, experiences of post-Soviet countries, such as Lithuania, Kazakhstan and Azerbaijan, in revamping their public sector performance and measurement system, and the extent to which the Soviet legacy has had an impact on the administrative system of these countries are analyzed.

Key words: State-building, measurement, performance, management, public sector. 